\title{
A synergistic approach of cross-cultural management and leadership style
}

\author{
Herciu Mihaela \\ Lucian Blaga University of Sibiu \\ Romania \\ mihaela.herciu@ulbsibiu.ro
}

\begin{abstract}
The ongoing growth of international business brings with it increasing demands associated with managing culturally diverse workforces. The cultural challenges that multinational companies must cope involve the synergistic approach of national cultural dimensions and leadership style. The present paper aims to evaluate the impact of these cultural challenges on international business by identifying the similarities and differences between cultural dimensions and leadership style based on correlation of Hofstede results and GLOBE scores.
\end{abstract}

Received:

May, 2014

1st Revision: September, 2014

Accepted:

October, 2014

DOI:

$10.14254 / 2071-$ $8330.2014 / 7-2 / 9$

Keywords: Cross-cultural management, cultural dimensions, leadership style, Hofstede, GLOBE.

JEL Classification: F23, M14, O57

\section{INTRODUCTION}

The stakes for managers have never been higher. The ongoing growth of international business brings with it increasing demands associated with managing culturally diverse workforces. Understanding culture is an asset, is has to be the first step in business internationalization process. In this context, multinationals have to understand workers (individuals) from various parts of the world which means to understand their culture. According to McFarlin and Sweeney (2011) the international managers have to: "approach other culture with the idea of testing sophisticated stereotypes; find cultural informants and mentors to help; carefully assess information that seems inconsistent with cultural stereotypes; learn mental maps that will increase effectiveness in different culture". More than that, they will need core cross-cultural competences to navigate the business through this increasingly complex and interconnected world of individuals, groups, nations, religious and civilizations (Slawomir, 2005).

Over the time, the impact of culture on business environment rose steadily. In the literature the concept of culture is related to: human resources management, leadership, change management, conflict management, and decision-making process, work attitude, individual/organizational behavior (Kirkman, 2006). Some authors asserting that national culture can explain the differences in economic growth between the countries. They also have identified some similar characteristics of cultural dimensions (Koen, 2005) and leadership style in order to create/develop cultural clusters. But, the practice of appropriated leadership style can transform cross-cultural differences into business opportunities. 


\section{CONCEPTUAL FRAMEWORK}

International business environment is very different from national business environment because countries, societies and cultures are different. It is not enough to be aware that cultural differences exist; you have to evaluate and transform them into business opportunities (Hill, 2007). Furthermore, there will be need to discover different ways to develop the global mindset of managers or leaders who act in international environment, such as: culture adaptability; bridging the gap; building global mentality; approach the cultural problems with caution. (Wild, Wild, Han, 2008).

The studies about culture and its impact on economic and business environment at national and international level have been developed from decades. Hofstede (1983), the well-known specialist in the field of national cultural dimensions, emphasized that "the national and regional differences are not disappearing; they are here to stay. In fact, these differences may become one of the most crucial problems for management - in particular for the management of multinational, multicultural organizations, whether public or private". In the same context, Negandhi (1983, p. 17) asserted that "the emerging field of cross-cultural studies on organizational functioning is largely a result of partial integration between the cross-cultural comparative management field and organization theory areas".

The types of cross-cultural management research vary from parochial research as a single culture studies to synergistic research as intercultural management studies (Adler, 1983). But in order to manage a corporation across culture manager must balance the similarities and differences. More than that, global managers sometimes cater to parochialism or simplification to manage these similarities and differences. According to Som (2009, p. 41), "parochialism is a way of looking the world through one's own lens, background and perspectives...while, simplification is a way of understanding that human beings who come from different cultures are still similar in their basic nature, relationship, modes of behavior and activities in time and space".

This means that managers have to develop the ability to integrate diversity across culture, on one hand, and have to be open to diversity across culture, on the other hand. If both integration and openness are high it is about global mindset. But if one is high and other is low we deal with parochial mindset (integration high and openness low) and with diffused mindset (integration low and openness high).

In our opinion, the most important analysis of national culture and cultural dimensions has been developed and conducted by Hofstede since 1980. The new Hofstede dimensions refer to (Hofstede, Hofstede, Minkov, 2010): power distance high/low; individualism/collectivism; masculinity/feminity; uncertainty avoidance high/low; long/short term orientation; pragmatism/normatism; indulgence/restraint. 
Hofstede's Cultural dimension

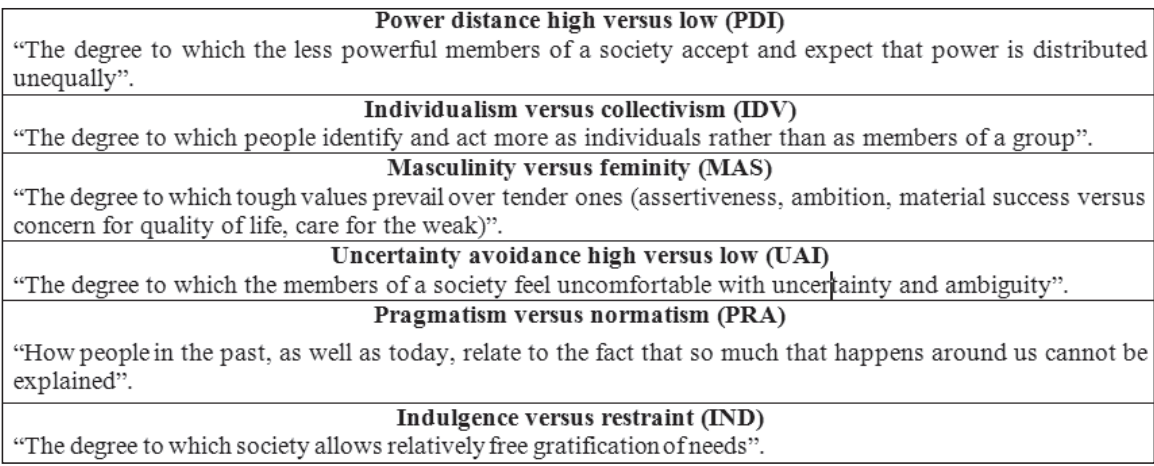

Cross-cultural research has been developed recently by Holden et al. (2002) through the GLOBE Project (Global Leadership and Organizational Behavior Effectiveness Research). The approach of cross-cultural management is a systemic one and is focus on: participation across culture; maintaining equivalence across culture, knowledge sharing; learning from experience. Also, they have developed a conceptual model that shows the influence of societal culture (with norms and practices) on both leader acceptance and effectiveness (Figure 1).

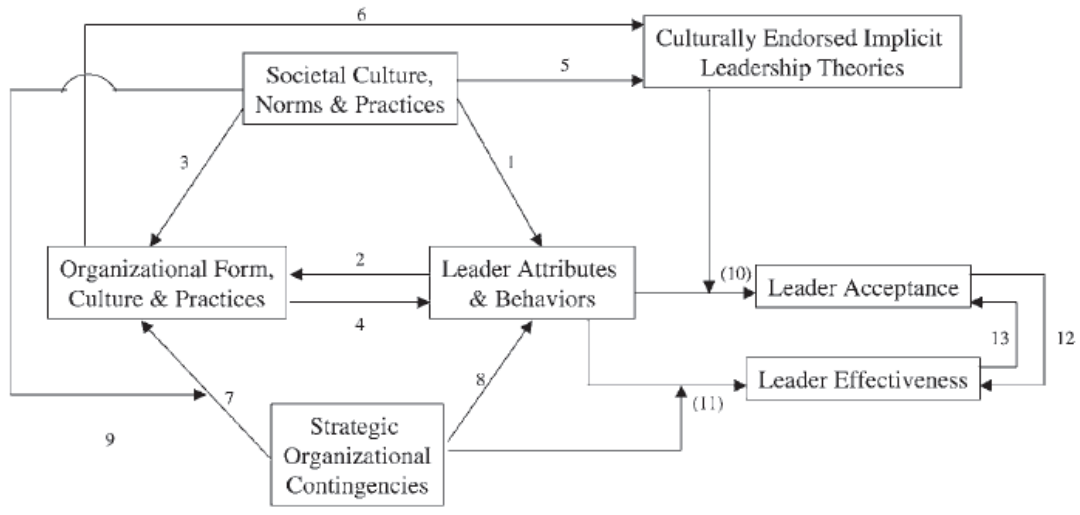

Figure 1: The GLOBE conceptual model

Source: (House, Javidan, Hanges, Dorfman, 2002, p. 8).

By GLOBE Project has been identified six leadership styles based on some cultural dimensions such as: power distance, uncertainty avoidance, human orientation, collectivism (institutional and in-group), assertiveness, gender equalitarianism, future orientation, performance orientation. Some of these are similar with Hofstede's cultural dimensions. The characteristics of every leadership style are presented in the Table 2 (House, 2002, p. 3). 
GLOBE Leadership style

\begin{tabular}{|c|}
\hline $\begin{array}{l}\text { Performance oriented style (PERF) } \\
\text { "Emphasizes high standards, decisiveness, and innovation; seeks to inspire people around a vision; creates a } \\
\text { passion among them to perform; and does so by firmly holding on to core values. This includes the facets of } \\
\text { visionary, inspirational, self-sacrificial, integrity, decisive, and performance-oriented". }\end{array}$ \\
\hline $\begin{array}{l}\text { Team-oriented style (TEAM) } \\
\text { "Instills pride, loyalty, and collaboration among organizational members; and highly values team cohesiveness } \\
\text { and a common purpose or goals. This style includes the facets of collaborative team orientation, team integrator, } \\
\text { diplomatic, (reverse scored) malevolent, and administratively competent". }\end{array}$ \\
\hline $\begin{array}{l}\text { Self-protective style (SELF) } \\
\text { "Emphasizes procedural, status-conscious, and 'face-saving' behaviors; and focuses on the safety and security of } \\
\text { the individual and the group. This style includes the facets of self-centered, status-conscious, conflict inducer, } \\
\text { face saver, and procedural". }\end{array}$ \\
\hline $\begin{array}{l}\text { Participative style (PART) } \\
\text { "Encourages input from others in decision-making and implementation; and emphasizes delegation and equality. } \\
\text { This style includes the facets of (reverse scored) autocratic and (reverse scored) non-participative". }\end{array}$ \\
\hline $\begin{array}{l}\text { Humane style (HUMA) } \\
\text { "Stresses compassion and generosity; and it is patient, supportive, and concerned with the well-being of others. } \\
\text { This style includes the facets of modesty and humane-oriented". }\end{array}$ \\
\hline Autonomous style (AUTO) \\
\hline
\end{tabular}

\section{THE IMPACT OF CULTURAL CLASH ON LEADERSHIP STYLE AND INTERNATIONAL BUSINESS}

When talking about two different culture and multinationals we talk about cultural clash. (Soderberg, Holden, 2002). Cultural differences can lead to a breakdown but also can provide some opportunities based on the diversity (Das, Kumar, 2010). In order to reduce this clash, managers or leaders have to: change their behavior in different culture, for example, if they activate in a collectivistic and high power distance culture, they have to adapt their style when is about individualist or low power distance culture (Varela, Salgado, Lasio, 2010); share within the multinational company knowledge, experiences, behaviors (Boyle, Nicholas, Mitchell, 2012); offer trainings and supportive actions to employees (Molinsky, 2007).

In this turbulent international environment, the management of culture represents an important organizational knowledge asset for multinational companies (Pauleen, Rooney, Holden, 2010). The model of transforming cross-cultural management into business opportunities through conversion of culture into a knowledge asset is presented in Figure 2.

Recently, some authors considered that in-country cultural regions are also very important. In order to identify business opportunities maybe is better to look inside of a country, to evaluate clusters from incountry regions (Minkov, Hofstede, 2012) because "even in highly individualistic societies, established firms are frequently not especially entrepreneurial... due to the intervening of corporate culture" (Morris, Davis, Allen, 1994, p. 66). The understanding of cultural differences will help individuals to work more effective (Husted, Allen, 2008) and will help companies to identify business opportunities terms of entry mode, performance, employees approach (Shenkar, 2001). 


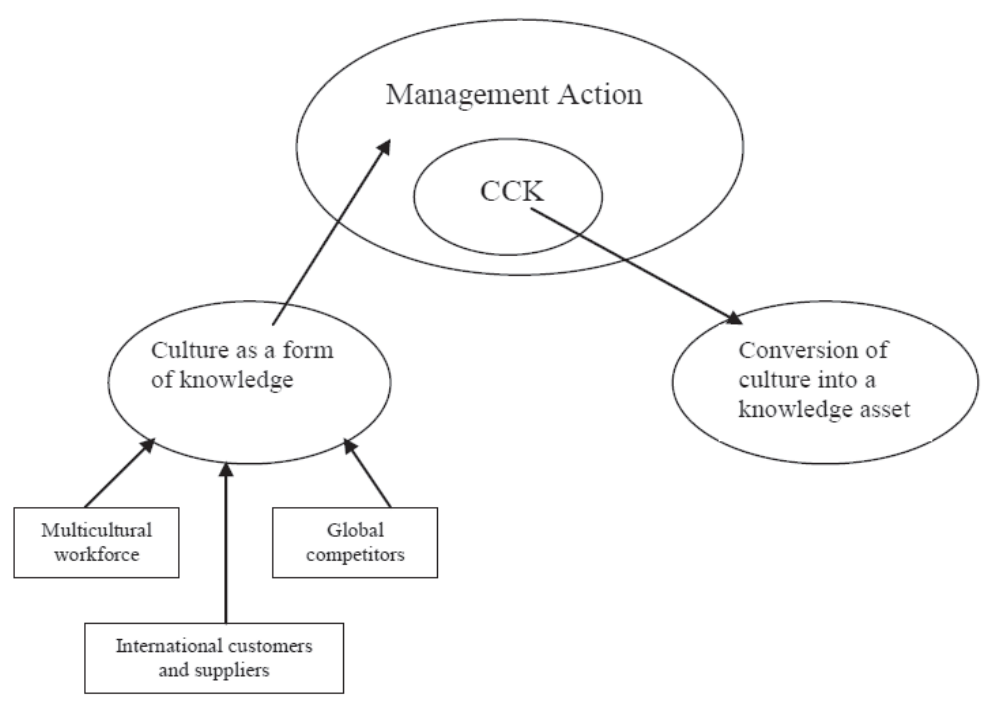

Figure 2: The model of Cross-Cultural Knowledge Management

Source: (Pauleen, Rooney, Holden, 2010)

The present study aims to analysis the synergy between Hofstede's cultural dimensions and GLOBE leadership style in order to evaluate the impact of cultural clash on leadership style. We have collected data for 31 countries (Annex 1), from different cultures: Latin America, Latin Europa, Confucianism, Eastern Europe, Anglo, Germanic, Nordic, and Southern Asia. Based on their results for cultural dimensions and leadership style we calculate the correlation index (CORREL) in order to identify the interrelations between them.

$$
\operatorname{CORREL}_{y / x}=\frac{n \sum x y-\left(\sum x\right)\left(\sum y\right)}{\sqrt{\left[n \sum x^{2}-\left(\sum x\right)^{2}\right]} *\left[n \sum y^{2}-\left(\sum y\right)^{2}\right]}
$$

Where,

$\mathrm{n}-$ the number of the elements/index/variable

$\mathrm{x}, \mathrm{y}-$ elements/indexes/variables to be considered if,

CORREL $_{\mathrm{y} / \mathrm{x}}$ is positive and tends to 1 , there is a strong direct connection between variables CORREL $_{\mathrm{y} / \mathrm{x}}$ is close to zero, may it come from 1 or -1 , than the connection between variables is weak CORREL $_{y / x}$ is negative and tends to -1 there is a strong inverted connection between variables 


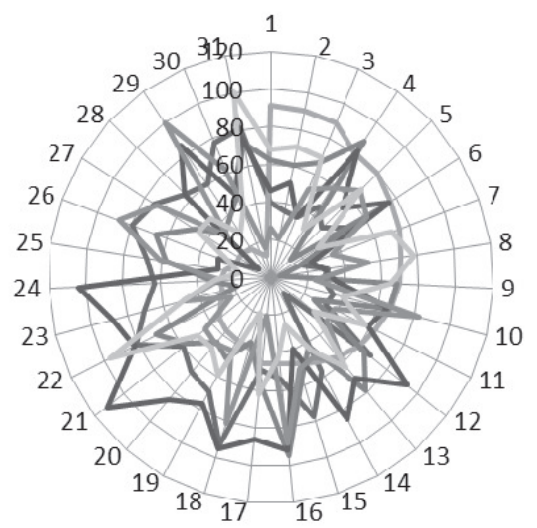

- Power dislance

-Individualism

- Masculinity

Uncertainty avoidance

- Pragmatism

- Indulgence.

1. Argentina; 2. Australia; 3. Austria; 4. Brazil; 5. China; 6. Denmark; 7. Finland; 8. Germany; 9. Greece; 10 Hong Kong; 11. Hungary; 12. India; 13. Indonesia; 14. Ireland; 15. Italy; 16. Japan; 17. Korea, Rep.; 18. Mexico; 19. Netherlands; 20. Poland; 21. Portugal; 22. Russia; 23. Singapore; 24. Slovenia; 25. Spain; 26. Sweden; 27. Thailand; 28. Turkey; 29. UK; 30. US; 31. Venezuela.

Figure 3: Hofstede's cultural dimensions

Source: (own representation based on Hofstede`s results)

According to Hofstede results the maximum and minimum levels for cultural dimensions are: Russia 93/Austria 11 for power distance; US 91/Venezuela 11 for individualism; Japan 95/Sweden 5 for masculinity; Greece 112/Singapore 8 for uncertainty avoidance; Korea Rep. 100/Venezuela 16 for pragmatism; Venezuela 100/Hong Kong 17 for indulgence.
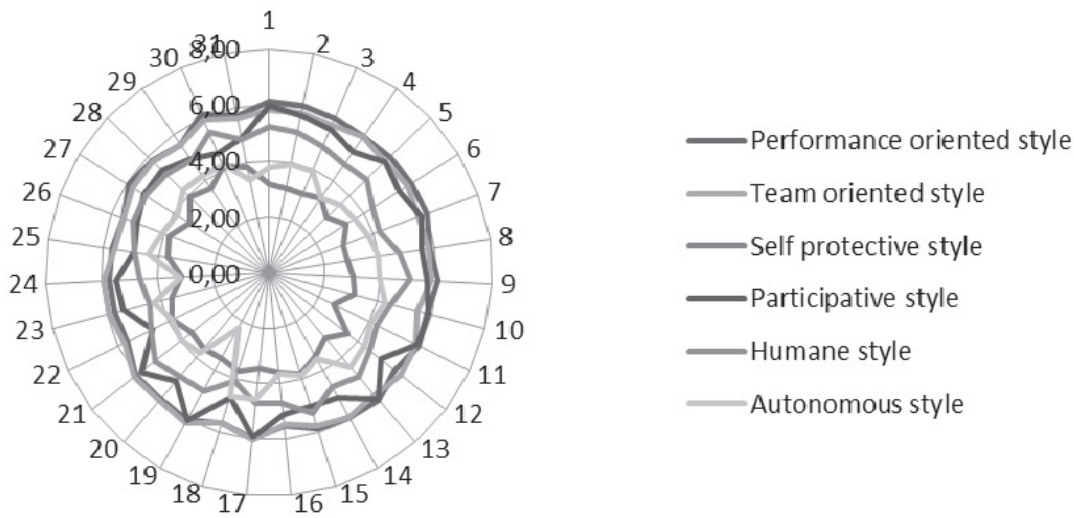

Team oriented style

Self protective style

—Participative style

-Humane style

-Autonomous style

1. Argentina; 2. Australia; 3. Austria; 4. Brazil; 5. China; 6. Denmark; 7. Finland; 8. Germany; 9. Greece; 10. Hong Kong; 11. Hungary; 12. India; 13. Indonesia; 14. Ireland; 15. Italy; 16. Japan; 17. Korea, Rep.; 18. Mexico;

19. Netherlands; 20. Poland; 21. Portugal; 22. Russia; 23. Singapore; 24. Slovenia; 25. Spain; 26. Sweden; 27. Thailand; 28. Turkey; 29. UK; 30. US; 31. Venezuela.

Figure 4: GLOBE Leadership style

Source: (own representation based on GLOBE results) 
Based on House (GLOBE) results the maximum and minimum levels for leadership style are: Indonesia 6.15/Japan 5.49 for performance oriented style; Brazil 6.17/Japan 5.46 for team oriented style; Indonesia 4.13/Finland 2.55 for self-oriented style; Brazil 6.06/Indonesia 4.61 for participative style; Indonesia 5.43/ Russia 4.67 for humane style; Russia 4.63/Brazil 2.27 for autonomous style.

To evaluate the synergy between cultural dimensions and leadership style we calculate the correlation indexes (CORREL) for all six dimensions with all 6 styles.

\begin{tabular}{|c|c|c|c|c|c|c|}
\hline CORREL & PERF & TEAM & SELF & PART & HUMA & AUTO \\
\hline PDI & -0.5042 & 0.0402 & 0.8324 & -0.7452 & 0.1372 & -0.0305 \\
\hline IDV & 0.5035 & 0.0491 & -0.7517 & 0.5615 & -0.2117 & -0.1035 \\
\hline MAS & -0.0620 & -0.1612 & 0.2629 & -0.1285 & 0.2551 & -0.0623 \\
\hline UAI & -0.2926 & 0.3405 & 0.2630 & -0.0989 & -0.3599 & -0.0838 \\
\hline PRA & -0.4147 & -0.5092 & 0.1638 & -0.2696 & -0.0532 & 0.1921 \\
\hline IND & 0.3309 & 0.0740 & -0.2988 & 0.3201 & 0.0530 & -0.2082 \\
\hline
\end{tabular}

According to correlation indexes (CORREL) in some cases Hofstede's cultural dimensions are strongly correlated with GLOBE leadership style, both directly and indirectly, such as: power distance with selfprotective style (directly), with performance oriented style and participative style (indirectly); individualism with performance oriented style and participative style (directly), with self-protective style (indirectly); pragmatism with performance oriented style and team oriented style (indirectly). These mean that: performance oriented style of leadership is practice on companies with a low power distance, less concentration of authority and direct appraisal of performance; team oriented style is based on personal stability and is focus on achieving group results; humane style and autonomous style are very different but they are present in every country drive by the managerial behaviour.

In order to sustain our results we mention other studies/articles that reflect and emphasize the link between culture (national culture with its dimensions) and leadership style. For example, Jung and Avolio (1999) examine the effects of leadership style and flowers' cultural orientation on performance; Den Hartog et al. (1999) and Dickson, Den Hartog and Mitchelson (2003) identify that specific aspects of charismatic leadership are strongly and universally endorsed across cultures. Bryne and Bradley (2007) conclude that cultural levels values influence on leadership style generates new strategies for management of international and global firms. Also, if we consider the micro-level, leadership and culture are fundamentally connected. Leadership style is strongly related to the organizational culture (Block, 2003) because leaders are the main architects of organizational culture and they influence the leadership style (Schein, 2010).

\section{CONCLUSION}

The capacity of understanding the importance of culture on business development and the capacity of transforming culture into knowledge asset represent major core competences for managers or leaders across the world. The cultural clash and the cultural challenges that multinational companies must cope involve the synergistic approach of national cultural dimensions and leadership.

Even if some of cultural dimensions and leadership style are not directly or indirectly connected, there are some conclusions that have to be emphasized. Russia is the country with the highest score for both power distance index and autonomous style (the self-centric approach of leadership). Despite the fact that Japan is the most masculine country based on our analysis, she had the lowest score for performance oriented style 
and team oriented style. In the Nordic Countries, those are recognized as the most feminist one, the leaders are less self-oriented, they are not self-centered, conflict inducers or procedural. The leaders from Confucian and Southern Asian countries are in the same time performance and humane oriented.

In conclusion, national culture has a huge impact on leadership style but also the leadership style influence the organizational culture of a company; it is about cross-cultural challenges and know-how managerial transfer.

\section{REFERENCES}

Adler, N., (1983), A typology of management studies involving culture, Journal of International Business Studies, fall, pp. $29-47$.

Block, L., (2003), The leadership-culture connection: an exploratory investigation, Leadership \& Organization Development Journal, 24(6), pp.318 - 334 .

Boyle, B., Nicholas, S., Mitchell, R., (2012), Sharing and developing knowledge of organizational culture during international assignments, International Journal of Cross Cultural Management, 12(3), pp. 361-378.

Byrne, G., Bradley, F., (2007), Culture`s influence on leadership efficiency: how personal and national culture affect leadership style, Journal of Business Research, 60(2), pp. 168-175.

Das, T.K., Kumar, R., (2010), Interpretive schemes in cross-national alliance, Cross Cultural Management, 17(2), pp. 154-169.

Den Hartog, D., House, R., Hanges, P., Ruiz-Quintanilla, A., Dorfman, P., (1999), Culture specific and cross-culturally generalizable implicit leadership theories: are attributes of charismatic/transformational leadership universally endorsed?, The Leadership Quarterly, 10(2), pp. 219-256.

Dickson, M., Den Hartog, D., Mtchelson, J., (2003), Research on leadership in a cross-cultural context: Making progress, and raising new questions, The Leadership Quarterly, 14(6), pp. 729-768.

Edfelt, R., (2010), Global Comparative Management: a functional approach, SAGE Publication Ltd, USA.

Hill, Ch., (2007), International business: competing in the global marketplace, McGraw-Hill/Irwin, USA.

Hofstede, G., (1983), The cultural relativity of organizational practices and theories, Journal of International Business Studies, fall, pp. 75-89.

Hofstede, G., (2006), What did GLOBE really measure? Researchers` minds versus respondents` minds, Journal of International Business Studies, no. 37, pp. 882-896.

Hofstede, G., Hofstede, Gert Jan, Michael Minkov, Cultures and Organizations: Software of the Mind, 3rd Edition, McGraw-Hill USA, 2010.

Holden, N., (2002), Cross-cultural management: A knowledge management perspective, Prentice Hall, London, UK.

House, R. (2002), Leader Effectiveness and Culture: The GLOBE Study, GLOBE, Centre for Creative Leadership, available at http://www.ccl.org/leadership/pdf/assessments/GlobeStudy.pdf.

House, R., Javidan, M., Hanges, P., Dorfman, P., (2002), Understanding cultures and implicit leadership theories across the globe: an introduction to project GLOBE, Journal of World Business, no. 37, pp. 3-10.

http://geert-hofstede.com/dimensions.html, Cultural dimensions, accessed on 10 March 2014.

Husted, B., Allen, D., (2008), Toward a model of cross-cultural business ethics: the impact of individualism and collectivism on the ethical decision-making process, Journal of Business Ethics, no. 82, pp. 293-305.

Jung, A., Avolio, B., (1999), Effects of leadership style and followers` cultural orientation on performance in group and individual task conditions, Academy of Management Journal, 42(2), pp. 208-218.

Kirkman, B., Lowe, K., Gibson, C., (2006), A quarter century of culture`s consequences: a review of empirical research incorporating Hofstede's cultural values framework, Journal of International Business Studies, no. 37, pp. 285-320. 
Koen, C., (2005), Comparative international management, McGraw-Hill Companies, 2005, UK

McFarlin, D, Sweeney, P., (2011), International management-strategic opportunities and cultural challenges, Taylor\&Francis, Reutledge.

Minkov, M., Hofstede, G., (2012), Is national culture meaningful concept? Cultural values delineate homogeneous national clusters of in-country regions, Cross-Cultural Research, 42(2), pp. 133-159.

Molinsky, A., (2007), Cross-cultural code-switching: the psychological challenges of adapting behavior in foreign cultural interactions, Academy of Management Review, 32(2), pp. 622-640.

Morris, M., Davis, A., Allen, J.W., (1994), Fostering corporate entrepreneurship: cross-cultural comparison of the importance of individualism versus collectivism, Journal of International Business Studies, first quarter, pp. 65-89.

Negandhi, A., (1983), Cross-cultural management research: trend and future directions, Journal of International Business Studies, fall, pp. 17-28.

Pauleen, D.J, Rooney, D., Holden, N.J. 2010, Practical wisdom and the development of cross-cultural knowledge management: a global leadership perspective, European Journal of International Management, 4(4), pp. 382-395

Ronen S, Shenkar O (1985), Clustering countries on attitudinal dimensions: a review and synthesis, Academy of Management Review, 10.

Schein, E., (2010), Organizational culture and leadership, John Wiley\&Sons, Inc.

Shenkar, O., (2001), Cultural distance revisited: towards a more rigorous conceptualization and measurement of cultural differences, Journal of international Business Studies, third quarter, pp. 519-535.

Slawomir, M., (2005), Cross-cultural competences, Taylor\&Francis, Reutledge.

Soderberg, AM., Holden, N., (2002), Rethinking cross cultural management in a globalizing business world, International Journal of Cross Cultural Management, 2(1), pp. 103-121.

Som, A., (2009), International Management - managing the global corporation, McGraw-Hill Education, UK.

Varela, O., Salgado, E., Lasio, M., (2010), The meaning of the job performance in collectivistic and high power distance culture. Evidence from three Latin American countries, Cross Cultural Management, 17(4), pp. 407-426.

Wild, J.J., Wild, K.L., Han, J.C.Y. (2008), International business: the challenges of globalization, Pearson Prentice Hall, USA. 
Annex 1

\begin{tabular}{|c|c|c|c|c|c|c|c|c|c|c|c|c|}
\hline Country & PDI & IDV & MAS & UAI & PRA & IND & PERF & TEAM & SELF & PART & HUMA & AUTO \\
\hline Argentina & 49 & 46 & 56 & 86 & 20 & 62 & 5.98 & 5.99 & 3.46 & 5.89 & 4.70 & 4.55 \\
\hline Australia & 36 & 90 & 61 & 51 & 21 & 71 & 6.09 & 5.81 & 3.05 & 5.71 & 5.09 & 3.95 \\
\hline Austria & 11 & 55 & 79 & 70 & 60 & 63 & 6.03 & 5.74 & 3.07 & 6.00 & 4.93 & 4.47 \\
\hline Brazil & 69 & 38 & 49 & 76 & 44 & 59 & 6.01 & 6.17 & 3.50 & 6.06 & 4.84 & 2.27 \\
\hline China & 80 & 20 & 66 & 30 & 87 & 24 & 5.57 & 5.57 & 3.80 & 5.05 & 5.18 & 4.07 \\
\hline Denmark & 18 & 74 & 16 & 23 & 35 & 70 & 6.01 & 5.70 & 2.82 & 5.80 & 4.23 & 3.79 \\
\hline Finland & 33 & 63 & 26 & 59 & 38 & 57 & 5.94 & 5.86 & 2.55 & 5.91 & 4.30 & 4.08 \\
\hline Germany & 35 & 67 & 66 & 65 & 83 & 40 & 5.84 & 5.49 & 3.15 & 5.88 & 4.50 & 4.30 \\
\hline Greece & 60 & 35 & 57 & 112 & 45 & 50 & 6.02 & 6.12 & 3.49 & 5.81 & 5.16 & 3.98 \\
\hline Hong Kong & 68 & 25 & 57 & 29 & 61 & 17 & 5.67 & 5.58 & 3.68 & 4.87 & 4.89 & 4.38 \\
\hline Hungary & 46 & 80 & 88 & 82 & 58 & 31 & 5.91 & 5.91 & 3.24 & 5.23 & 4.73 & 3.23 \\
\hline India & 77 & 48 & 56 & 40 & 51 & 26 & 5.85 & 5.72 & 3.78 & 4.99 & 5.26 & 3.85 \\
\hline Indonesia & 78 & 14 & 46 & 48 & 62 & 38 & 6.15 & 5.92 & 4.13 & 4.61 & 5.43 & 4.19 \\
\hline Ireland & 28 & 70 & 68 & 35 & 24 & 65 & 6.08 & 5.82 & 3.01 & 5.64 & 5.06 & 3.95 \\
\hline Italy & 50 & 76 & 70 & 75 & 61 & 30 & 5.99 & 5.87 & 3.26 & 5.47 & 4.37 & 3.62 \\
\hline Japan & 54 & 46 & 95 & 92 & 88 & 42 & 5.49 & 5.46 & 3.61 & 5.08 & 4.68 & 3.67 \\
\hline Korea, Rep. & 60 & 18 & 39 & 85 & 100 & 29 & 5.53 & 5.53 & 3.68 & 4.93 & 4.87 & 4.21 \\
\hline Mexico & 81 & 30 & 69 & 82 & 24 & 97 & 5.66 & 5.75 & 3.86 & 4.64 & 4.71 & 3.86 \\
\hline Netherlands & 38 & 80 & 14 & 53 & 67 & 68 & 5.98 & 5.75 & 2.87 & 5.75 & 4.81 & 3.53 \\
\hline Poland & 68 & 60 & 64 & 93 & 38 & 29 & 5.67 & 5.98 & 3.53 & 5.05 & 4.56 & 4.34 \\
\hline Portugal & 63 & 27 & 31 & 104 & 28 & 30 & 5.75 & 5.92 & 3.11 & 5.48 & 4.62 & 3.19 \\
\hline Russia & 93 & 39 & 36 & 95 & 81 & 20 & 5.66 & 5.63 & 3.69 & 4.67 & 4.08 & 4.63 \\
\hline Singapore & 74 & 20 & 48 & 8 & 72 & 46 & 5.95 & 5.77 & 3.32 & 5.30 & 5.24 & 3.87 \\
\hline Slovenia & 71 & 27 & 19 & 88 & 49 & 48 & 5.69 & 5.91 & 3.61 & 5.42 & 4.44 & 4.28 \\
\hline Spain & 57 & 51 & 42 & 86 & 48 & 44 & 5.90 & 5.93 & 3.39 & 5.11 & 4.66 & 3.54 \\
\hline Sweden & 31 & 71 & 5 & 29 & 53 & 78 & 5.84 & 5.75 & 2.82 & 5.54 & 4.73 & 3.97 \\
\hline Thailand & 64 & 20 & 34 & 64 & 32 & 45 & 5.78 & 5.76 & 3.91 & 5.30 & 5.09 & 4.28 \\
\hline Turkey & 66 & 37 & 45 & 85 & 46 & 49 & 5.96 & 6.01 & 3.58 & 5.09 & 4.90 & 3.83 \\
\hline UK & 35 & 89 & 66 & 35 & 51 & 69 & 6.01 & 5.71 & 3.04 & 5.57 & 4.90 & 3.92 \\
\hline US & 40 & 91 & 62 & 46 & 26 & 68 & 6.12 & 5.80 & 3.16 & 5.93 & 5.21 & 3.75 \\
\hline Venezuela & 81 & 12 & 73 & 76 & 16 & 100 & 5.72 & 5.62 & 3.82 & 4.89 & 4.85 & 3.39 \\
\hline
\end{tabular}

Source: (Hofstede, 2010 and House et al. 2002) 